\title{
Researching Joe Pawelka
}

\section{MICHAEL JACKSON}

\section{A lecture given for the Stout Research Centre, October 1996.}

All stories get subtly reworked and reconstrued each time they are told. To extend Heraclitus's metaphor of time and the river, one might say that it is impossible to tell exactly the same story twice. And this is as true of rumour, as of folktales, and of the most rigorously d o c u m en t ed events. Even when print promotes an illusion of fixity and fosters the belief in an authorized version, stories are inevitably revised as they pass through the hands and minds of their readers.
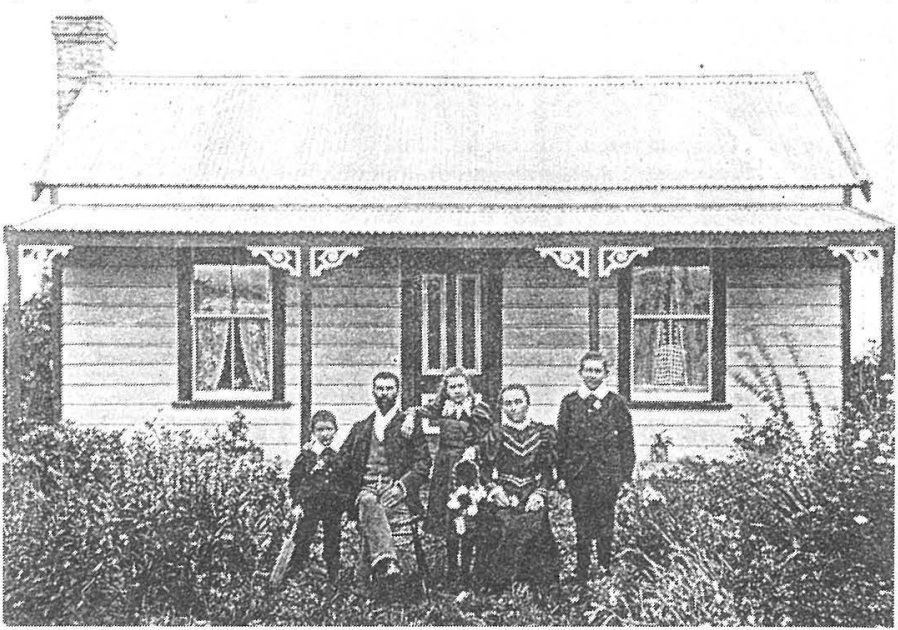

Despite a common heritage, we are shaped by different backgrounds, histories, and desires, and the stories we tell and retell - like wet clay shaped between a potter's hands - carry the imprints and traces of our individual lives.

My most recent book concerns one of new Zealand's most notorious and facinating fugitives, Joe Pawelka, and my talk tonight touches on some of the twists and turns of my research into his life and times, including the unsolved mystery of his fate.

The bare bones of the story are well known. In 1910, when he was 22, Joe Pawelka was arrested in the Manawatu and remanded on charges of housebreaking, arson and theft. His escape from police custody triggered the most intense manhunt in New Zealand since the military pursuit in the late 1860 s of the Maori resistance leader Te Kooti. During the weeks that Pawelka was on the run, two men were shot dead, buildings were set on fire, shops and homes burgled, and panic engulfed a province.

Recaptured and brought to trial, Joe Pawelka got twenty one years hard labour, a sentence many consid-

The Pawelka family outside their Kimbolton house around the turn of the century. Joe Pawelka is standing to his mother's right. The other children are Jack and Agnes. ered vengeful and unjust. On the wintry August day in 1911 when Pawelka escaped from The Terrace gaol in Wellington never to be heard of again, there was widespread feeling that poetic justice had been done.

The Pawelka story first emerges in the newspapers of the time, with journalists making the most of the dramatic events taking place in a region where the commonest crimes were riding a bicycle at night without a lamp, being drunk and disorderly, rigging scales and using false weights, playing hooky, and allowing stock to stray onto a public thoroughfare. But within a year of Pawelka's es-

cape, the story is retold by a Wellington newspaperman, Albert William Organ (1912), and for seventy years, until another Wellington journalist, Des Swain, recasts the Pawelka story in a quasi-fictional way, celebrating Joe as a hard-done by romantic hero, Organ's True Life Story of Joseph John Pawelka: His Crimes, Sentences, Prison Career, and Final Escape (1912) remained the account on which encyclopaedia articles, TV scripts, and the Pawelka legend were based. In part the story of Man Alone, it belongs to the diffuse and dimly lit world of our collective imagination, blurring with countless other popular stories, pub yarns and anecdotes, and resembling a kind of national self portrait on which we work tirelessly, unselfconsciously, and without much sense of the finished picture.

I first heard of Joe Pawelka from my grandfather. He was a policemen in Levin in 1910, and among the police reinforcements brought to the Manawatu for the Pawelka manhunt. An immigrant himself, with working-class origins, he had a lot of sympathy for Joe Pawelka, and sharing his reminiscences with me, his young grandson, was one way in which he came to terms, in his retirement, with the questions of social justice and human dignity that preoccupied him all his life.

Stories have a habit of generating stories. They come 
to nest, one inside the other, like Chinese Boxes, each a window onto another's world, and when, 20 years ago, I went to live in the Manawatu, places where Joe Pawelka lived, worked, and took refuge became part of my life too. In a poem I published in $1977^{1} \mathrm{I}$ alluded to some of the ways in which my story and Joe Pawelka's story were beginning to come together in my imagination:

This poem has been written before;

it has been written by men and women who never read a line of poetry all their lives; it has been said and imagined many times; it is the poem of the labyrinth, of the other way, of forgotten roads and of the wheel of chance and today, travelling the Pahiatua track to Scarborough, I think of Joe Pawelka and what went wrong for him, my grandfather's story of a hunted man who vanished from the cells in which he was condemned for burning down a school, housebreaking and escape, for bothering his wife when the magistrate ordered their separation, who scrawled a note with the lead of a bullet and signed it "a man against the world."

Though I'd always wanted to find out "what went wrong" for Joe Pawelka it wasn't until two years ago that I set about the task. But my research did not stop with Joe Pawelka. It led me from the past into the present, and brought me to consider questions of fate and belonging that are as pressing now as they were at the turn of last century. Inevitably, too, my research implicated my own story. In looking for Joe Pawelka I found myself trying to come to terms with my own small-town New Zealand upbringing, to rethink my own New Zealandness in the light of my increasingly attenuated relationship with the country that I still called home.

In the National Library and Archives I covered ground that previous researchers had covered, and formed a picture of a close-knit family of working-class Catholic Moravian migrants struggling to make a go of it in the predominantly Protestant and Anglo settlement of Kimbolton a hundred years ago. I learned that Joe had not got on with his quick tempered father, that he had been pampered by his mother, that he felt bitter and bereft when he was forced to leave school at thirteen and become a butcher's apprentice.

On his twenty first birthday he was admitted to Palmerston Public Hospital with typhoid fever, and barely survived the operation on his lungs. After convalescing under his mother's care, he took work with a Palmerston butcher, but was sacked because of his habitual lying. Ten days after losing his job he stole some meat and a steel from another butcher, and three weeks later burgled the house of a Palmerston lawyer.

After a brief courtship, he married Hannah Elizabeth Wilson. The marriage lasted only two months. Possibly Lizzie feared her husband's mood swings, his histrionic threats against those who had crossed him, the revolver he had hidden in the house. Though pregnant, she filed a court application for "summary separation" and went back to live with her widowed mother in Ashhurst. In an attempt to win Lizzie's sympathy, Joe tried to drown himself in the Manawatu river, but all he got for his pains was a fine and a court order to pay his estranged wife maintenance.

Unable to imagine or endure life without Lizzie, Joe now began to fill their vacant house with stolen furniture and furnishings. It was as if the empty dwelling embodied his loss and served as a sore reminder of the bourgeois world in which he had failed to find a place. As if he imagined that by filling the house with things taken from the family homes of others, his stolen happiness would be magically restored.

In fact, Joe lost everything. Charged with numerous thefts of furniture and furnishings from houses in Palmerston, he was remanded in custody. Two weeks later he escaped and made it back to Kimbolton only to be rearrested the following day and taken to Wellington for trial. Again he escaped, and returned to the Manawatu. Breaking through police cordons, he tried to see his wife, and one windswept night left a note in a milk can in Ashhurst protesting his innocence of the crimes that the papers were daily attributing to him. Scrawled with the lead of a bullet, the note was signed: 'J Powelka, a man against the world'.

The rest is history. Arrested in a hay barn outside Ashhurst where he had taken shelter from torrential rain, he railed against false accusations and then, in custody, defeated and weeping, begged to see Lizzie. When told she would not come he asked to be given poison to finish himself off.

At his trial in Wellington he was charged with a string of break-ins and burglaries, with burning down a furniture store and High School, with escape, and with the murder of a policeman. Though found not guilty of murder, he got the maximum sentence the law allowed. But within six months, after four unsuccessful attempts at escape, he broke out of Wellington's maximum security prison in The Terrace with the help of other prisoners, and was never recaptured.

At this point, the subject of my research was snared by the stereotypes and stories that had gathered around Pawelka and taken on a life of their own. One such stereotype is immediately recognizable in the photo on the 1910 police poster that is still in circulation, still conditioning our 
idea of who he was. The rigidity of the mugshot, with its formal placement of the hands, and the prisoner literally up against a wall, evokes an image of a body in death. Made over as a criminal type, Pawelka suffers our gaze and our judgement. His name, his history, his background, his thoughts, his voice are invalidated. The frozen image has taken him over. He is trapped inside the frame as in a cage, and even now we find it hard to see him otherwise.

To know another person's soul, to read another person's mind, one must find that person within oneself. One has to locate in one's own experience something that corresponds roughly to the other person's experience - that can provide common ground and assist comparison. This is why, from the outset of my research, I found myself digressing into my own life. But a second strategy for finding one's way into another person's life is to trace the ways in which that life has impinged upon and shaped the lives of others.

When I finished my archival research in Wellington I went back to the remote Aboriginal settlement in North Queensland where I had been living for half a year. But the Pawelka story had taken hold of me, and three months later I came back to Wellington to pursue Joe Pawelka's life in the lives of those who outlived him.

Taking a lead from Richard Hill, my first step was to visit Ray Carter, a retired senior constable who had interviewed members of the Pawelka family when researching his history of the Palmerston North police district. Ray had met Joe's sister Agnes in 1985, a few months before she died, and Agnes had not hidden her contempt for journalists. Sensitive to her hurt, Ray did not even broach the subject of her brother's fate. "It was the same with my

The police poster circulated after Pawelka's escape in 1910. National Archives, Wellington. interview with Jack Hansen," Ray told me. "I began to interview him but never followed it up."

Jack was Agnes' son and Joe's nephew. He had run the store in Kimbolton that his father established in 1891, but was now retired and living in the back of the shop.

One of the leads I was following was a photograph. Apparently, some time during the first world war, Joe's parents received a photo of a group of soldiers clipped from a newspaper. There were about thirty soldiers in the photograph. They were in a desert somewhere. Around one of the soldiers in the back row a circle had been drawn. The family were unable to decipher the postmark on the envelope, and there was no letter to indicate who had sent the photo or why.

When I met Jack, I mentioned the photo Ray had described to me.

Jack remembered the photo, but had no idea what had become of it. It was actually a photo Joe's mother Louisa clipped from a newspaper - of a group of American or Canadian soldiers in France. Louisa was convinced that one of the soldiers in the photo was Joe, but Jack was inclined to think it was wishful thinking, something for her to hang on to. That Joe had never contacted his mother, that he had broken his promise to write her and broken her heart was something Jack could not forgive.

I asked if Joe's family ever spoke of him.

"Seldom, if ever," Jack said. It was only when he was in his twenties and asked outright that he was told anything. The family kept its own counsel. Partly it was fear of prosecution for having aided and abetted the fugitive. Partly it was shame - because of the ill-repute Joe brought upon them. "It was hard," Jack said. "It was always hard for the mother."

Jack explained how the family sheltered Joe during the six months between the spring of 1911 and the sum- 
mer of 1912. Apparently, Jack's father, Willie, who was married to Joe's sister Agnes, organized everything. Joe's mother cooked meals. Willie smuggled them to an old grainstore across the road from his shop where Joe was in hiding. But the whole community was complicit. When, years later, the Kiwitea County Council bought the old grainstore to convert it into a garage, some musty old prison clothes were discovered under the floorboards. Supposing them to have belonged to Joe Pawelka, the Council presented them to Willie Hansen as a souvenir.

When and how did Joe leave Kimbolton? I asked Jack.

Again, Willie Hansen planned everything. He got a friend, a local farmer, to buy train tickets to Auckland and a boat ticket to Vancouver. The Pawelkas, Hansens, and Willie Hansen's friend, scraped up the money for the fare, and arranged for a young man called Ted Lawrence, who worked on the farm, to accompany Joe to Auckland.

Joe's father took him to Mangaweka on February 15 1912, hidden under sacks in a dray. Ted Lawrence travelled on horseback separately. The two men boarded the Auckland train in the evening. Next day, Ted and Joe had only a short walk from the Auckland railway station to the new Queen Street wharf where Joe was to board a ship for Canada.

Having got Joe onto the boat, Ted went ashore. He returned to say goodbye not long before the boat sailed, but couldn't find Joe anywhere. So there was no certainty that Joe actually sailed.

After my conversation with Jack Hansen, I went back to the National Archives in Wellington. I figured that since Joe Pawelka would not risk sailing under his own name, his assumed name might contain some small clue as to his true identity. So I began combing shipping lists.

At five in the afternoon of 16 February, 1912 - the day Ted Lawrence and Joe Pawelka reached Auckland - the R.M.S. Makura (4920 tons) sailed from the new Queen Street wharf, bound for Vancouver, via Suva and Honolulu. Arriving early that same morning from Sydney, the Makura loaded a large consignment of butter and hides for Vancouver, as well as ten tons of general cargo for Suva and Honolulu. She carried 246 passengers, 149 of whom embarked in Sydney.

In Auckland that day, the wind was fresh and from the south. The afternoon air temperature was $70^{\circ} \mathrm{F}$.

My heart was pounding as I scanned the names. On the strength of what Jack had told me about people scraping together money for Joe's fare, I assumed he would not

have had a saloon or second-class ticket, so gave my most careful attention to the steerage passengers, 15 of whom had boarded in Auckland. In the lists, they were designated 'labourers and domestics'. Of the 12 men, one was travelling with his wife. The destination of another, $\mathrm{Mr}$ Peterson, was Honolulu. The 10 remaining names, written in longhand and difficult to decipher, suggested nothing.

Despite drawing a blank, I decided to photocopy the Makura passenger lists, as well as lists for the Morea which sailed from Auckland for Sydney and London the same day. Unfortunately, there was, an archival assistant informed me, a "blanket restriction" on photocopying shipping lists.

I asked if I could speak with the archivist.

I was told it would be a long wait.

The delay proved fortuitous. With time to kill, I went back to the Shipping Indexes. When was the next sailing from Auckland?

The Makura sailed on Friday. The next sailing was on Monday, February 19th. The S.S. Wimmera (1871 tons) crossed the Tasman twice a month.

I now worked my way through the names of the steerage passengers on the Wimmera. Seventy-six were men. One was a Mr J. Wilson.

I was sure I had tracked him down. He must, I told myself, have had recourse to his second name, John. The thought that he might assume Lizzie's maiden name had already occurred to me. But what really clinched the matter was my discovery, next day, in the shipping advertisements of The New Zealand Herald for February 1912, that tickets purchased for sailings on Union Steamship Company boats were interchangeable with Huddart Parker the company that owned the Wimmera.

Was it possible that Joe Pawelka had not sailed for Canada after all? Keeping his plans to himself, had he

Hansen's Store, Kimbolton, 1901. 
come to a decision to cover his tracks, cut off all ties with his past, and never look back? When he gave Ted Lawrence the slip in Auckland, was it his intention that no one, not even his family, would know where he was going? As an escaped and hunted criminal, there was no future for him in New Zealand. His wife had washed her hands of him. His family had been obliged to farewell him forever. Under these circumstances, did he choose to die to the life that was now dead to him? Did he turn against the world which he imagined had turned against him, in an act of metaphorical suicide? An act of spite as much as it was an act of survival.

Many of the men who crossed the Tasman in steerage each summer were shearers. Joe Pawelka could have fallen in with them, disembarked in Sydney, gone inland. When war was declared, he may have enlisted. There was a real possibility that he numbered among the thousands of ANZAC casualties at Gallipoli.

So far, nothing has come of this line of inquiry, despite my extensive searches in Australian war archives and Registers of Births, Deaths and Marriages. I tell myself now that it doesn't matter. But I do not want to bring my story to an end, as others have done, by imagining what happened.

Yet was I not a writer, a storyteller. And don't all stories demand closure?

Every story is also a journey. Not only are stories frequently about journeys; they imitate the shape of journeys - a movement from some troubled homeplace out into the wilderness of the world, and finally a return, when the protagonist, wiser for what he or she has been through, resumes the life that was held in abeyance for as long as the journey lasted.

It was almost a year before my story found its ending. It happened in Kimbolton, where Joe began, and where I returned to see Jack Hansen one more time.

During my year away I had written a draft of my book and sent copies to Jack, as well as to Anne Harris, Joe's granddaughter, whom I had met in Wellington during my previous visit. I told them there were pieces missing from the mosaic, but that these pieces belonged not to the past but to the present. Already I knew that the most compelling thing about Joe Pawelka's story, the thing I wanted to write about, was the way his story had become transmuted into others. The real story was the story of these people - who had survived Joe's disappearance, who had had to deal with the stigma of loss, humilation and disgrace: Louisa, who, in Jack's words "took to her garden and rosary beads", Joseph senior, who "took to the grog", Lizzie who bore his child and tried to erase his name, Agnes, Jack and Helen, Joe's siblings, who bore the brunt of gibes and gossip in their turn. Their stories were the way I brought my story to an end.

In August last year I came back to Kimbolton, to a "round table conference" Jack had arranged to "solve the remaining pieces of the puzzle".

It was the weekend of the America's Cup, and when I saw the Marque Vue sparkling wine in Jack's fridge I thought our conference would be overshadowed by this event. But no, the champagne was to celebrate what Jack called the family reunion. This would be the first time all of Joe's living descendants had come together. Anne drove up from Wellington, and John and Fay - Helen's children - came from Wellington and Wanganui with their spouses. Everyone had files and boxes of photos, genealogies, and family memorabilia. There was even a revolver Joe had made when he was a boy - a sawn-off.22 rifle, with the patent mark of H. Pieper's, Liege, Belgium engraved on the bevelled barrel.

Though my research had been the catalyst for our meeting, Joe Pawelka did not dominate it. For Joe's nephews and niece, clearing up the mystery of his disappearance 83 years ago was far less urgent than affirming their survival as a family. As John, Fay, Jack, and Anne began to share their photos and memorabilia, the talk was less of Joe than of his sisters, Agnes and Helen, who had struggled to escape his shadow.

Fay recalled some of her mother's memories. Of when she was eight and came home from school at lunchtime with a friend one day to find Joe in the kitchen with Louisa. Of the police poking pitch forks into the haystack behind the house, but too afraid to go into the hay shed lest Joe was hiding there.

But mostly Helen said nothing of her brother.

"Any time I mentioned the name Pawelka, the walls came up," John said.

"She felt shame," John's wife, Maria, added. "It ruined her life. You can't imagine what it was like back then. Joe's brother Jack never married because he carried the Pawelka name. He didn't want his children to be stigmatised by having to carry it too."

"We were never allowed to mention his name," Fay said. "Mum didn't keep some of the things she got from Louisa. She destroyed a lot of things that had to do with Joe. She was ashamed of the memory."

When she was 87, Agnes wrote her nephew about a television film that was being made about her brother. She said: "When Joe disgraced us, we lost touch with everyone, thinking they would not want to have anything more to do with us. I suppose we were too sensitive; and now it's all going to be dragged up again in a film. I wish God I was dead and out of it. There is no doubt about the innocent having to suffer for the guilty unto the third or fourth generation. People are so cruel ..."

Joe's guilt had become metamorphosed into the family's shame.

Despite everything, Louisa kept a faithful record of every rite of passage in the life of the family, and when Fay showed me Louisa's prayer book, it was like being given a glimpse into the family's soul. 
The small, battered Catholic missal measured about three inches by five. The boards were covered in purple cloth. There was a tarnished metal cross on the front cover. The binding was broken. I had to turn the dogeared, age-blotched, brittle pages with care.

In several pages in the front and back of the book, Louisa had, over the years, written details of births, deaths and marriages. Here was the date of her arrival in New Zealand, and of her marriage to Joe senior when she still called herself Louise König. Here were the birthdays of her sons, Joseph John Thomas (Joe) and John Alfred (Jack), and of her daughters Agnes and Florence Helen. Here also were the dates on which her children left home.

One page arrested me. Though the right hand edge of the page was tattered, making it impossible to decipher two of the dates, here, at last, was confirmation of the date of Joe's final leave-taking. His name, Joseph John Thomas, was reduced to initials, possibly to disguise a potentially incriminating fact:

J.J.T left home 15th

Feb 1912

A later entry reads:

Joe left home 15th

Feb 1912

"She wrote him out of her life," Jack said.

Our lives are storied. Were it not for stories, our lives would be unimaginable. Stories make it possible for us to overcome our separateness, to find common ground and common cause. To relate a story is to retrace one's steps, going over the ground of one's life again, reworking reality to render it more bearable. A story enables us to fuse the world without and the world within. In this way we gain some purchase over events that confounded us, humbled us, left us helpless. In telling a story we renew our faith that the world is within our grasp.

Consider the stories occasioned by Joe Pawelka's life.

A psychotherapist might discern in the circumstances of Joe Pawelka's childhood, in his recorded remarks, and in his behaviour under stress, a picture of clinical narcissism. Convinced that fate has singled him out as a victim of injustice, this individual will do anything to draw attention to himself. To this end, heroism and notoriety, affection and contempt, are on a par. Deep down he remains a resentful child who thinks he deserves to be pandered, and when the going gets rough appeals to others for rescue and care. Thus the overweening and remorseless need for acceptance. The habits of feigned illness and sham dementia. The threats of suicide, the manipulative confabulations, the downright lies. Such aggressive narcissism is an attempt to bend the world to one's will. One's sole reality is one's own needs, one's own feelings, one's own state of mind. By contrast, the world of others is weightless and colourless; effectively does not exist.
There may be grains of truth in this picture. But it is only a picture underexposed and poorly developed.

Of all the stories which invoke fact, perhaps none are more tenacious than newspaper stories. Written in the confident if naive belief that "getting the facts right" will also settle the attendant moral, legal and political issues, such stories quickly take on a life of their own.

When The Weekly News commissioned an article on Joe Pawelka in 1936, the rationale was that the facts be given precedence over personal sensibilities and possible slights. Thus, despite assuring Louisa that the story had been killed when she objected to its publication, the editor defended his right to publish it. Writing to Joe's younger brother, Jack, he argued: "I can understand your unwillingness to have the case needlessly re-opened to go over the facts as they have been published before, but I would point out to you that the author has had full access to police and other records and has gone to great trouble with his story with the object of doing your brother justice. Surely Joseph Pawelka has a right to have his name cleared. There is no shame for his family in this."

The editor went on to stress that the public was fascinated by the Pawelka story, and he urged Jack Pawelka to appreciate the need to have "the facts put straight" in "the interests of pure history."

The Pawelka family rejected this argument, and fifty years later was still opposed to the idea of raking over dead coals.

In 1987, broadcaster and freelance journalist Des Swain began his research on Joe Pawelka, and met with the same resistance.

In a letter to Iris McGaffin- Joe's and Lizzie's daughter - whom he had traced through a birth certificate, marriage records, and electoral rolls, Swain sought to mollify her by painting a flattering portrait of Joe and pointing out that he could not have killed McGuire and did not shoot to kill Pauline Kendall. Testifying to the "positive aspects of his character," Swain wrote: "I am satisfied that a large number of comments about Joe Pawelka had no basis in fact: that he was a much better man than people are led to believe."

Iris was elderly and ill when she received Swain's letter. Not wanting to confront the spectre of the past, she did not reply. But her son Terry wrote John Bryce, suggesting he contact Swain. Terry made one stipulation: "Mum requests that you do not involve the newer generation, i.e. her children, and grandchildren."

Not long after Des Swain began work on his "historical novel," Anne Harris learned of her kinship with Joe Pawelka. And the story she came to tell was also steeped in romanticism. "I'm a terrible romantic," Anne told me. "Lizzie and Joe must have been so in love. In Anne's view Joe couldn't do enough for his young bride, but had very little money, "so when he had a chance to acquire some inexpensive furniture he jumped at it." Anne was aware 


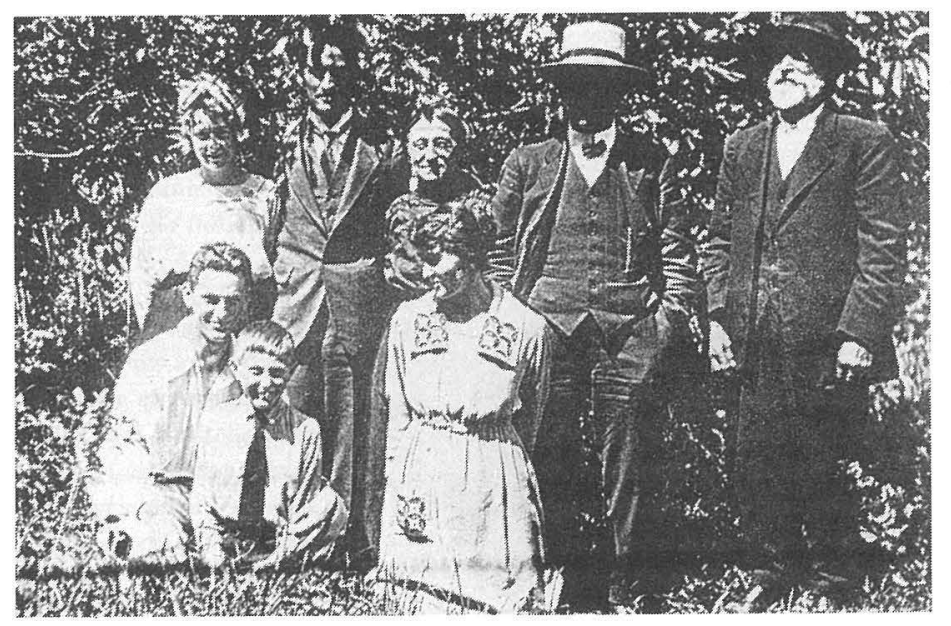

anything, it was a celebration of being free of his legacy. Greater than any sense of his presence was the sense of Helen's absence. If shame is a kind of perpetual grieving, then the family, working through their grief over Helen's death, had at last begun to unburden itself of the shame it had shared with her.

Helen had been the last of Joe's generation. "An afterthought," Fay said. Much younger than the others, she was the last to have known Joe in life. Though Jack liked to tell me that if Helen had been alive my research would have beer easier, I knew that it would have been harder,

that this was very likely not what happened. "It's my theory," she said. "It's based on the sort of thing I'd do."

For Joe's parents and siblings, such heroic nostalgia would have been as futile as the argument of the editor of The Weekly News: that proving Joe innocent of the violent crimes of which he was accused would alleviate his descendants' shame and stigma. The fact is, however, that for Joe's immediate family there was no redemptive myth.

While Joe's maternal grandmother told herself that Joe's tragic life was divine retribution for his parents decision to marry against her will, Louisa and Joseph could never bring their son's story to a close. It had a beginning, a middle, but no end... though Louisa may have imagined some God-given resolution in the afterlife. Until their own deaths ended their self-questioning, they kept their silence and implored others to do the same. For the children's sake. In the hope that in forgetfulness and the fullness of time their pain might ease.

What then of the story I had written?

John Berger observes that "any story drawn from life begins, for the storyteller, with its end." Most stories, he goes on to say, "begin with the death of the principal protagonist. It is in this sense that one can say that storytellers are Death's secretaries. It is Death who hands them the file."

At Jack's "round table" in Kimbolton I had been a ghostly eavesdropper, registering a story which at times brought. tears, at other times laughter. But though I was privy to these unrehearsed recollections and shared memories, I was an outsider. Almost a voyeur.

What had brought us together? And why now?

Our meeting had little to do with vindicating Joe. If

Christmas Day early 1920s, near the end of Joseph senior's life. He stands on the right. Next to him is Willie Hansen, then Louisa, then Joe's brother Jack and younger sister Helen. Kneeling in the foreground is Agnes, Jack Hansen, and his half-brother Ken. because I, like the others, would have been bound by the same taboo against talking about the past - the sole defence Helen and the others had against further hurt. The generosity with which John and Fay showed me Helen's heirlooms, and confided to me what they remembered of her and Joe, expressed their freedom from an old constraint.

But this was only my guess. For Jack and the others, our meeting was a mystery. "It's strange that after all these years everything is coming together," he had told me, and mentioned how one of the South Island Pavelkas got in touch at the very same time I began work on the story.

But as soon as we tried to clear up the mystery, we found ourselves again standing in Joe's long shadow.

Anne was convinced that Joe's spirit had brought us together. John's wife, Maria, agreed. Joe's spirit had presided over our meeting. It was Joe who inspired Barbara Blyth (nee Pavelka) to contact the others last year. And it had been Joe who had moved me to write my book.

George Santayana once observed that those who cannot remember the past are condemned to repeat it. But what is the point of remembering the past unless it helps us get beyond the situation that has shaped the way we are?

Overshadowing the spadework of the scholar are the claims of the living. The limits placed on what we may know of Joe Pawelka are not fixed by the paucity of the evidence as to his character, his guilt, or his ultimate fate. They are set by the exigencies of the time and place in which we live.

Forays into the past are justified, I like to think, only when the past gives us some guidelines for how we can live less divisively and more generously in the here and now.

\section{NOTE}

1. Latitudes of Exile: Poems 1965-1975. John McIndoe: Dunedin 